INSIGHTS INTO REGIONAL DEVELOPMENT

ISSN 2669-0195 (online) http://jssidoi.org/IRD/

2021 Volume 3 Number 4 (December)

http://doi.org/10.9770/IRD.2020.3.4(6)

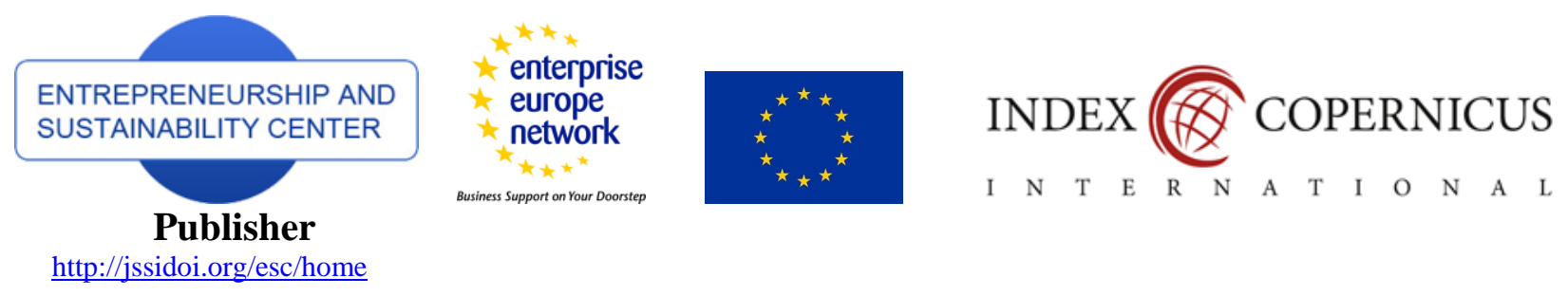

\title{
PECULIARITIES OF EMPLOYEE PROFESSIONAL DEVELOPMENT IN THE WORLD, EUROPEAN UNION AND LATVIA*
}

\author{
Valdis Jukšs \\ Daugavpils University, Vienibas street 13, Daugavpils, Latvia \\ E-mail: Valdis.Jukss@du.lv
}

Received 18 September 2021; accepted 29 November 2021; published 30 December 2021

\begin{abstract}
Within this study, employee professional development is conceptually understood as a component of lifelong learning. The concepts of lifelong learning, a learning society and even a learning economy are popular and theoretically justified as necessary prerequisites for the competitiveness and the economic performance of countries in the modern world. The problem is that Latvia (like most countries with low economic performance) is still not a learning society - especially compared to the countries of the European Union. In this regard, it became necessary to empirically measure the economic importance of employee professional development in the modern world in order to justify the management of lifelong learning based on the economic paradigm. For an empirical interpretation of lifelong learning and employee professional development, the author used the Global Talent Competitiveness Index (GTCI) and indicators of the economic performance of the world's countries for the period from 2018 to 2020. Applying four methods of quantitative data analysis - correlation analysis, regression analysis, comparison of means and discriminant analysis, the author proved the following: in the modern world, employee development is mainly a factor, but also an indicator of competitiveness and economic performance of countries, since significant investments are required to implement employee professional development. Nevertheless, the sustainable management of lifelong learning and the self-motivation of employees helps to create a learning society not only based on material investment, but also through the development of a learning culture.
\end{abstract}

Keywords: employee professional development; economic importance; lifelong learning; learning society; sustainable management; European Union; Latvia

\footnotetext{
* This research was supported by the project, which has received funding from the European Union's Horizon 2020 research and innovation programme European Research Council (ERC) under the European Union's Horizon 2020 research and innovation programme Marie Sklodowska-Curie Research and Innovation Staff Exchanges ES H2020-MSCA-RISE-2014 CLUSDEVMED (2015-2019) Grant Agreement Number 645730730
}
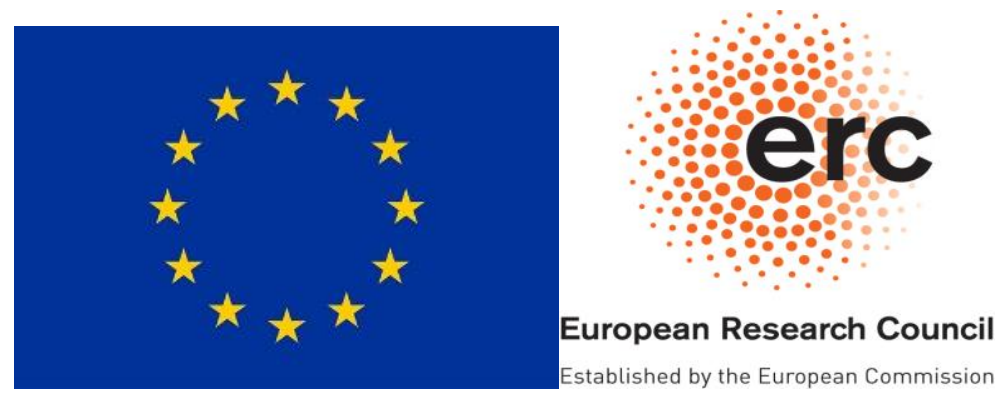


\section{INSIGHTS INTO REGIONAL DEVELOPMENT}

ISSN 2669-0195 (online) http://jssidoi.org/jesi/

2021 Volume 3 Number 4 (December)

http://doi.org/10.9770/IRD.2020.3.4(6)

Reference to this paper should be made as follows: Jukšs, V. 2021. Peculiarities of employee professional development in the world, European Union and Latvia. Insights into Regional Development, 3(4), 80-100. http://doi.org/10.9770/IRD.2021.3.4(6)

JEL Classifications: C18, D22, E70

\section{Introduction}

In scientific and analytical literature, employee professional development is conceptually understood as a component of lifelong learning (INSEAD et al., 2017, 2018, 2019, 2020; Bersin \& Zao-Sanders, 2019; Beqiri \& Mazreku, 2020). The relevance of lifelong learning in the world is due to the increasing role of education in the economy, caused by the change in the global economic model in the 21 st century. This global economic model assumes a transition from an industrial economy to a knowledge economy (Boronenko, 2007; Rivza, 2018). The concept of lifelong learning is to continue professional development after graduation, since the knowledge gained quickly becomes outdated (Su, 2007).

In turn, the economic essence of lifelong learning is associated with the fact that people's knowledge becomes a real factor of production. This knowledge is capable of creating high added value, and at the same time is a demanded product in the market (Sannikova, 2015). The Latvian researchers I. Lapinya and D. Aramina concluded that "the increase in the general professional level of the labor force is one of the main determinants of economic development" (Lapina \& Aramina, 2011: 63). As automation, artificial intelligence and new workplace models are reshaping the business environment, lifelong learning is becoming not only a pedagogical but also an economic imperative (Zao-Sanders, 2019). 80\% of business leaders around the world believe that the need for new skills is the biggest challenge in their business (PwC, 2021).

Some scholars emphasize that lifelong learning is necessary in order to meet the increased demand in the labor market for a new skills of employees (Galindo-Rueda et al., 2003). Education today is no longer limited to a certain age, it is economically necessary throughout life and becomes an integral part of it (Zborovskij \& Ambarova, 2020). In this regard, a new term appears in the terminological space - "learning society". The development of a learning society is determined by three main factors: the information society, the scientific and technological environment and the internationalization of the economy (EC, 1995).

The concept of a learning society has been studied for a relatively long time and is actively used in the international scientific space (Hutchins, 1968; Husen, 1974; Edwards et al., 1995; Jarvis, 2000, 2006; Welton, 2005; Su, 2007; Popescu, 2011; Tindemans \& Dekocke, 2020; Seriakova \& Kravchenko, 2020; Sungsup et al., 2021; Raven, 2021), but practically not used in Latvia (at least in Latvian publications). G. Chen and R. Klimoski argue that there is a gap between training and development theories and empirical research in this area. In this regard, empirical research at the macro level is needed to better understand how employee professional development affects macroeconomic indicators (Chen \& Klimoski, 2007).

The aim of this study is to theoretically substantiate and to empirically measure the economic importance of employee professional development in the modern world. The author intends to pay the special attention to the position of Latvia against the background of the world's countries and especially the EU countries as well as to answer the research question: can Latvia be called a learning society? Methodologically, the author's research is based on a conceptual understanding of employee professional development as a component of lifelong learning, which is of particular value in the knowledge economy.

The source of empirical information for this study is data for 2018-2020 from reports on the Global Talent Competitiveness Index (GTCI) for more than 100 countries of the world (including all EU countries) (INSEAD et 


\section{INSIGHTS INTO REGIONAL DEVELOPMENT}

ISSN 2669-0195 (online) http://jssidoi.org/jesi/

2021 Volume 3 Number 4 (December)

http://doi.org/10.9770/IRD.2020.3.4(6)

al., 2018, 2019, 2020). The author uses GTCI (more precisely, one of its pillars) as a tool for empirical assessment of the relationship between the employee professional development and the economic performance of the modern world's countries over three years. In the course of the empirical study, several methods were used in order to obtain more stable results: correlation analysis, regression analysis, comparison of means and discriminant analysis.

\section{Conceptual understanding of employee professional development as a component of lifelong learning}

In the modern social science, a learning society is considered the ideal and economically optimal model for the development of education (Seriakova \& Kravchenko, 2020). According to P. Edwards, a learning society is, first of all, an educated society characterized by active citizenship, liberal democracy and equal opportunities for lifelong learning (Edwards et al., 1995).

Most researchers working in the field of lifelong learning theoretically consider a learning society as an undeniable factor of success both for the employees themselves and for the organizations in which they work, as well as for a society and an economy as a whole. For example, the scholars Th. Beqiri and I. Mazreku write that lifelong learning is an important part of people's working life and that it is also important for employers. Investing in the employee skills through formal and non-formal education increases the creativity, resilience and efficiency of employees. In turn, enterprises that invest in improving the skills of their employees become competitive both domestically and internationally. The potential benefits of employee professional development may not be obvious and do not always follow immediately after training, but it certainly increases competitiveness (Beqiri \& Mazreku, 2020). Th. Beqiri and I. Mazreku especially emphasize the need for continuous employee development in those countries "that are still in transition and for which the current problem is the lack of employee skills" (Beqiri \& Mazreku, 2020: 95).

In turn, the International Labor Organization in its conceptual article "Lifelong learning: concepts, issues and actions" emphasizes that lifelong learning also characterizes the future of educational systems and units. Educational systems and units must be flexible and capable of preparing workers for the labor market even after they have embarked on their professional careers. Educational systems and units should also motivate employees to constantly learn in order to be ready for situations when it will be necessary to change jobs (ILO, 2019).

Furthermore, crises like the Covid-19 pandemic are accelerating historically determined trends and processes within lifelong learning. In any case, today there is an excellent opportunity: the long-overdue need for systemic adaptation to more suitable forms of education has received a unique impetus. The period for creating new educational systems can be shortened by innovative processes launched or accelerated by the pandemic. The overall goal of lifelong learning is to ensure that everyone can successfully meet life's challenges in an everchanging world (Tindemans \& Dekocke, 2020).

Colleges and universities are beginning to recognize the importance of lifelong learning beyond the traditional model of earning credit points and degrees. Some of the learning stages take place in the framework of interest education and are important both for employees and employers as well as for a society (Aspin \& Chapman, 2007). In this regard, the term "learning economy" appeared in the scientific literature (Lundvall, 2016). According to the author, it is more functional than the term "knowledge economy", since it focuses not on an economically valuable product - knowledge, but on the process of obtaining it, i.e. learning. In turn, learning itself also has market value, and modern economic and management science should pay special attention to this issue.

The economic influence of educational units is significant at all levels of social life, since people continue formal education throughout their lives and master certain subjects in accordance with their interests. Educational units carry out economic activities and "produce" educated citizens who buy goods and services in the economy. Like 
healthcare units, educational units are one of the largest employers in many places in the world. Whether educational units operate face-to-face or remotely, they have a large socioeconomic impact on education for all age groups (Zborovskij \& Ambarova, 2020). In the process of constantly improving and expanding their education, people try to find themselves in more valuable professions, influencing the economic, social and cultural life of local communities (Aspin \& Chapman, 2007).

In the OECD Skills Strategy, five priority tasks are formulated for the new lifelong learning system: (1) development of learning culture; (2) reducing disparities in employee skills; (3) improving the skills used at work; (4) improving the management of lifelong learning; (5) optimization of funding for lifelong learning (OECD, 2019). This document clearly defines a common purpose: a society that learns to become a competitive society with an advanced economy. Then scientists are faced with the following research question: if the answer is lifelong learning, then what is the problem? According to the author of the article, the main problem is that, according to the OECD data, many OECD countries are still not learning societies. This is especially true for that part of the employed population of the OECD countries, which most of all needs to learn, i.e. for low-skilled employees (Figure 1). This problem, in turn, may indicate other hidden problems in the field of lifelong learning in general and employee professional development in particular.

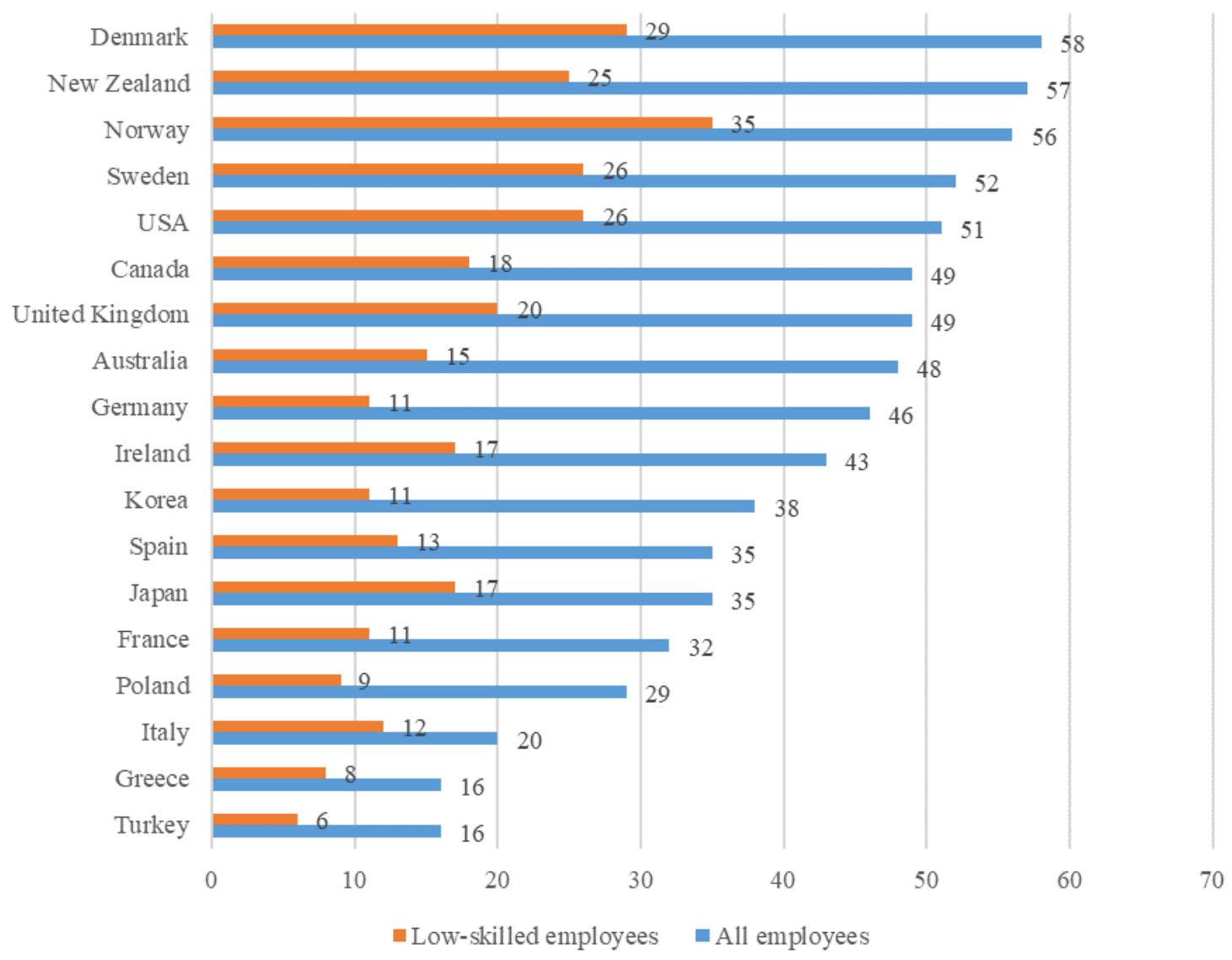

Fig. 1. Participation of the employed population in selected OECD* countries in professional development, all empolyees and low-skilled employees, \%, 2019

* The OECD mean is $41 \%$ for all employees and $18 \%$ for low-skilled employees.

Source: OECD, 2019. 


\section{INSIGHTS INTO REGIONAL DEVELOPMENT}

ISSN 2669-0195 (online) http://jssidoi.org/jesi/

2021 Volume 3 Number 4 (December)

http://doi.org/10.9770/IRD.2020.3.4(6)

B. Tindemans and V. Dekocke, the experts of the Center of Expertise on Innovative Learning Pathways (Brussel) consider the following as a serious problem: despite the fact that the industrial age has passed and the learning context has completely changed, in the modern world's countries, the educational systems in most cases have not yet adapted to the new requirements of life. The current educational system has been developing over the course of decades, when the first professional diploma obtained was at the same time the last stage of education. This diploma provided the young people with a socio-economic status, allowing them to take a worthy place in the industrial society. Today, the learning process itself is largely still organized as an industrial production process, in which schoolchildren or groups of students sit in classrooms. They are crammed into timelines similar to work hours, and the school bell indicates that work has begun or is completed. The educational work itself is divided into stages depending on the age of the students. The next stage of the educational process depends on the mean points obtained in the previous stages (Tindemans \& Dekocke, 2020).

With regard to the new educational system, B. Tindemans and V. Dekocke write that "all generations and all residents should be included in it. When the educational system has a social and economic impact on every citizen, when we have learning enterprises and organizations, when obstacles are removed and innovative solutions for lifelong learning are developed, then it becomes possible to create a learning society in which every person can grow and develop in any new socio-economic context" (Tindemans \& Dekocke, 2020: 5).

In scientific literature (mainly European and North American (Kyndt \& Baert, 2013; Boeren, 2016; Webb et al., 2019)), as well as in declarations and analytical reports of international institutions and organizations - European Commission, OECD, UNESCO (EC, 2000; UNESCO, 2015a, 2015b, 2016; OECD, 2019) - there is consensus on the concept of lifelong learning, based on three principles: (1) the central role of the learner; (2) focus of learning on transitional situations and processes; (3) a plurality of forms and contexts of learning. It is especially emphasized that people can learn throughout their lives in different contexts and conditions - not only at school, but also in the workplace, in a family environment, during their free time, participating in the community life, and so on. Furthermore, different learning models in terms of duration, time and type are recognized in the literature (OECD, 2019).

In the global scientific space, there are two paradigms that try to explain and analyze the participation of people in lifelong learning in general and employee professional development in particular. The first and dominant one, the economic paradigm, focuses on competitiveness in a rapidly changing knowledge society (Dahlman et al., 2007). The second, the humanistic paradigm, argues that the ideal of development is a civil, socially integrated society (UNESCO, 2015b). But sometimes the conceptual understanding of lifelong learning and employee professional development is based on these two paradigms at once (Panitsides et al., 2012), since the ability of people to cope with changes and live in a socially integrated society is precisely a prerequisite for being competitive in the modern labor market (Tindemans \& Dekocke, 2020).

In turn, the ability of an educational system to ensure economic performance, effectively using the resources of present and future generations is an object of sustainable management. Sustainable management is defined as the application of sustainable practices in different fields by management in a manner that is beneficial to present and future generations (Sekhar, 2020). The following figure schematically presents the conceptual understanding of sustainable management of employee professional development as a component of lifelong learning within the economic paradigm. 


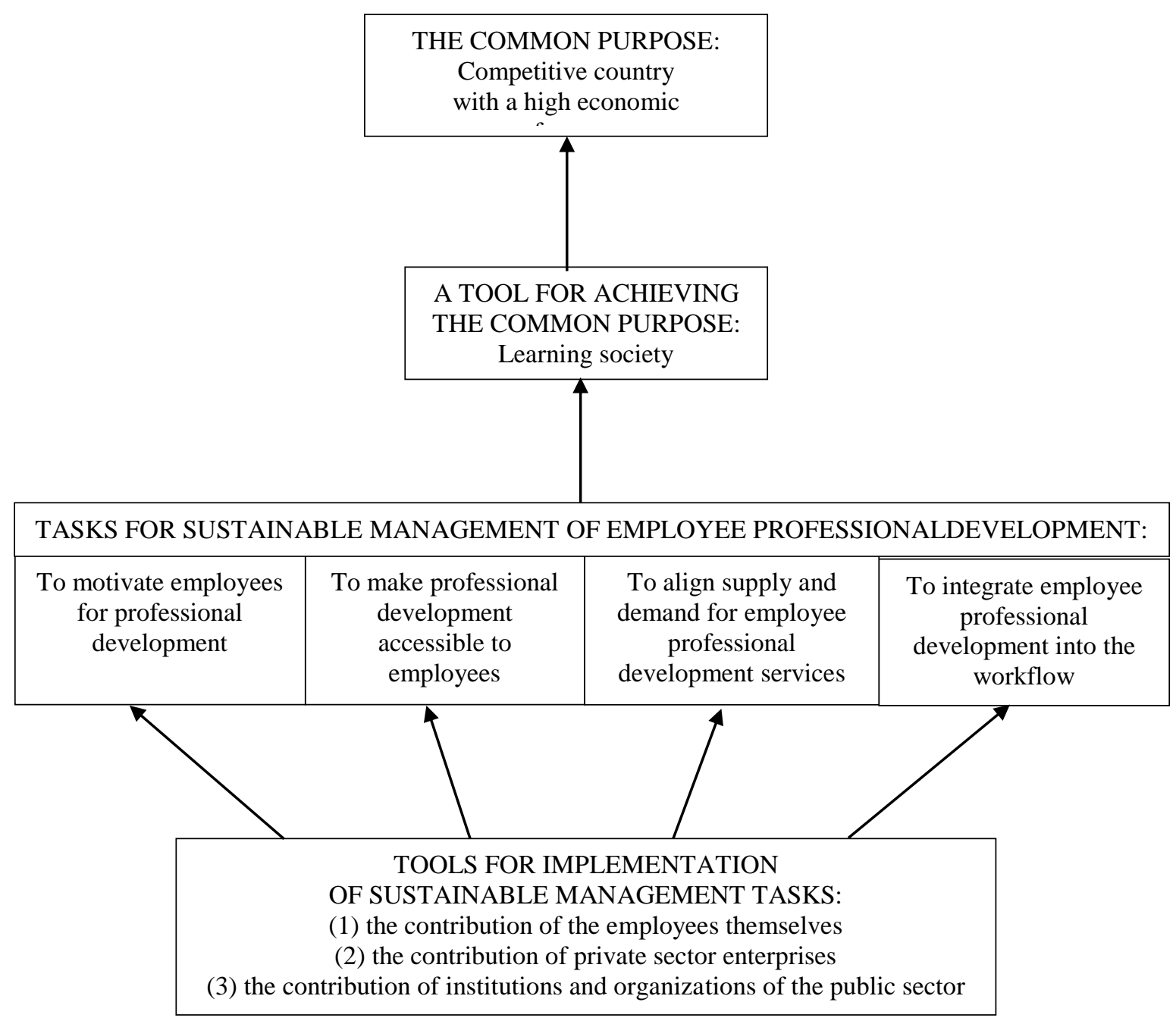

Fig. 2. The conceptual understanding of sustainable management of employee professional development within the economic paradigm

Source: elaborated by the author based on Webb et al., 2019; Tindemans \& Dekocke, 2020.

In the conception presented in Figure 2, the central place in the process of achieving the country's competitiveness and its high economic performance is given to the employees themselves, because "the person himself/herself learns and learning begins directly with him/her. Moreover, learning can be successful only if the learner is internally motivated" (Tindemans \& Dekocke, 2020: 10). This is in line with the definition given by UNESCO: "lifelong learning is a continuous, voluntary and self-motivated acquisition of knowledge for personal or professional development. Only then does lifelong learning not only contribute to social inclusion, active citizenship and personal development, but also competitiveness and employability" (UNESCO, 2016). Selfmotivation is the hallmark of targeted professional development - as opposed to incidental or random learning. Incidental or random learning can be "an additional product" of daily activities, events or communication, and it does not represent a purposeful learning process to achieve the employee's perceived professional goals" (Tindemans \& Dekocke, 2020). 
INSIGHTS INTO REGIONAL DEVELOPMENT

ISSN 2669-0195 (online) http://jssidoi.org/jesi/

2021 Volume 3 Number 4 (December)

http://doi.org/10.9770/IRD.2020.3.4(6)

\section{Methodology for empirical assessment of the economic importance of employee professional development}

As already mentioned in the Introduction to this article, the author considers the Global Talent Competitiveness Index (GTCI) as the most appropriate tool for empirical assessment of the economic importance of employee professional development in the modern world. With the help of GTCI, it is possible to link the conceptual understanding of the sustainable management of employee professional development as well as the country's competitiveness and its high economic performance, on the one hand, and empirical observations in this area, on the other.

The following figure shows schematically the place of lifelong learning and its component "Employee development" in the general structure of the GTCI.

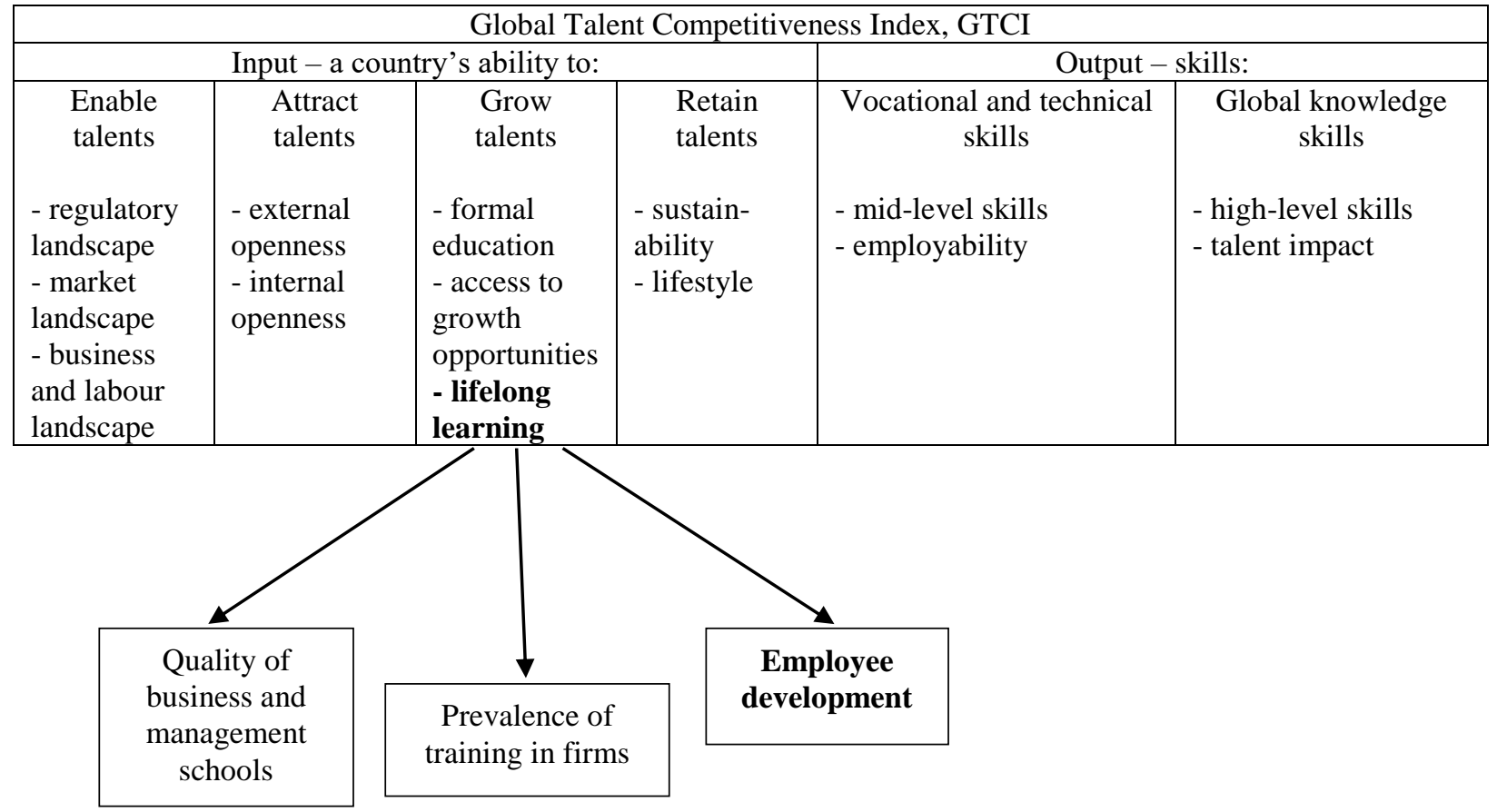

Fig. 3. The place of continuous learning and the component of employee development included in it in the general structure of the Global Talent Competitiveness Index (GTCI)

Source: elaborated by the author based on INSEAD et al., 2017.

The conceptual essence of the GTCI is that the modern world's countries compete with each other in the global economic space by growing, attracting, enabling and retaining talents that ensure competitiveness and economic performance of countries (INSEAD et al., 2017). In turn, lifelong learning (along with formal education and access to growth opportunities) is a sub-pillar of the GTCI's pillar "Grow talents" (Figure 3). The pillar "Grow talents" characterizes the ability of the world's countries "to produce" their own talents, and not attract them from outside. Its sub-pillar "Lifelong learning" includes the following three components (INSEAD et al., 2018, 2019, 2020): 


\section{INSIGHTS INTO REGIONAL DEVELOPMENT}

ISSN 2669-0195 (online) http://jssidoi.org/jesi/

2021 Volume 3 Number 4 (December)

http://doi.org/10.9770/IRD.2020.3.4(6)

- quality of business and management schools, which is measured by the scale from 1 (extremely poor - among the worst in the world) to 7 (excellent - among the best in the world), an average answer of experts ${ }^{\dagger}$ to the question: "In your country, how do you assess the quality of business schools?"

- prevalence of training in firms, which is measured by the proportion of firms offering formal training (\%);

- employee development, which is measured by the scale from 1 (not at all) to 7 (to a great extent), an average answer of experts to the question: "In your country, to what extent do companies invest in training and employee development?"

In order to adjust for differences in units of measurement and ranges of variation, all variables are normalized into the $[0,100]$ range, with higher scores representing better outcomes. A min-max normalization method was adopted, given the minimum and maximum values of each variable respectively (INSEAD et al., 2018, 2019, 2020).

The following table 1 shows those results of the GTCI statistical audit conducted by the European Commission Joint Research Center that belong to sub-pillars of the GTCI's pillar "Grow talents" and link them to all pillars of the GTCI. These results are obtained by the analysis of statistical coherence of the GTCI, which includes principal components analysis and multi-level analysis of the correlations between variables.

The table shows the statistical coherence between the sub-pillars of the GTCI's pillar "Grow talents" - formal education, access to growth opportunities, lifelong learning - and all six pillars of the GTCI to determine how strong the individual sub-pillars of the GTCI's pillar "Grow talents" define the world countries' ability to grow talents, and how strongly - other aspects of the countries' talent competitiveness.

Table 1. Statistical coherence in the Global Talent Competitiveness Index: correlation between sub-pillars of the "Grow talents" and pillars of the GTCI, correlation coefficients, 2017

\begin{tabular}{|c|c|c|c|c|c|c|}
\hline \multirow{3}{*}{$\begin{array}{l}\text { Sub-pillars of the } \\
\text { GTCI's pillar } \\
\text { "Grow talents" }\end{array}$} & \multicolumn{6}{|c|}{ Global Talent Competitiveness Index, GTCI } \\
\hline & \multicolumn{4}{|c|}{ Input - a country's ability to: } & \multicolumn{2}{|c|}{ Output - skills: } \\
\hline & Enable talents & Attract talents & Grow talents & Retain talents & $\begin{array}{l}\text { Vocational and } \\
\text { technical skills }\end{array}$ & $\begin{array}{c}\text { Global } \\
\text { knowledge } \\
\text { skills }\end{array}$ \\
\hline Formal education & 0.68 & 0.46 & 0.89 & 0.78 & 0.76 & 0.83 \\
\hline $\begin{array}{l}\text { Access to growth } \\
\text { opportunities }\end{array}$ & 0.82 & 0.76 & 0.90 & 0.77 & 0.69 & 0.80 \\
\hline $\begin{array}{l}\text { Lifelong } \\
\text { learning }\end{array}$ & 0.74 & 0.72 & 0.84 & 0.60 & 0.54 & 0.60 \\
\hline
\end{tabular}

Source: the part of the table from Saisana et al., 2017: 87.

The data in Table 1 indicate that the ability of the modern world's countries to grow talents is correlated, firstly (by 90\%), with access to growth opportunities, and secondly (by 89\%), with the state of formal education in a

\footnotetext{
$\dagger$ The World Economic Forum's Executive Opinion Survey (EOS) is conducted on an annual basis to gather information from business leaders on topics for which hard data sources are scarce or nonexistent (World Economic Forum, Executive Opinion Survey: http://reports.weforum.org).

$\$$ The Enterprise Survey is a firm-level survey of a representative sample of an economy's private sector. The survey covers a broad range of business environment topics including access to finance, corruption, infrastructure, crime, competition, and performance measures. Since 2005-06, under its developed Global Methodology, the World Bank's Enterprise Analysis Unit has collected these data based on over 135,000 interviews with top managers and business owners in about 140 economies (every year - a different quantity of countries) (World Bank, Enterprise Surveys: www.enterprisesurveys.org ).
} 
country, and thirdly (by 84\%), with lifelong learning. It should be noted that, despite the fact that lifelong learning is the least statistically significant part in the overall ability of the modern world's countries to grow talents, in percentage terms, the difference between the significance of all three sub-pillars is small. Thus, all three subpillars of the GTCI's pillar "Grow talents" are most strongly correlated with the ability of the modern world's countries to grow talents (and not with other aspects of the countries' talent competitiveness).

As for the correlation of lifelong learning with other pillars of the GTCI, we can say that lifelong learning is most strongly correlated with those pillar of the GTCI, which it belongs to - with the pillar "Grow talents". At the same time, lifelong learning is quite strongly correlated with such aspects of the countries' talent competitiveness, as their ability to enable talents (by 74\%) and to attract talents (by 72\%) (Table 1).

Table 2. Lifelong learning components' importance at the various levels of the GTCI structure, 2017

\begin{tabular}{|c|c|c|c|c|}
\hline $\begin{array}{c}\text { Components } \\
\text { of the sub-pillar } \\
\text { "Lifelong learning" }\end{array}$ & \multicolumn{4}{|c|}{ Captured part of the variance: } \\
\hline $\begin{array}{l}\text { Quality of business and } \\
\text { management schools }\end{array}$ & $61 \%$ & $59 \%$ & $58 \%$ & $57 \%$ \\
\hline Prevalence of training in firms & $65 \%$ & $34 \%$ & $20 \%$ & $16 \%$ \\
\hline Employee development & $64 \%$ & $54 \%$ & $65 \%$ & $59 \%$ \\
\hline
\end{tabular}

Source: the part of the table from Saisana et al., 2017: 88.

The data in Table 2 indicate that lifelong learning's component "Employee development" captured $64 \%$ of the variance within the GTCI sub-pillar "Lifelong learning", 54\% - of the variance within the GTCI pillar "Grow talents", 65\% - of the variance within Input of the GTCI and 59\% - of the total variance within the GTCI. Thus, lifelong learning's component "Employee development" is the most statistically significant among lifelong learning's components both for this sub-pillar itself, and for the GTCI factorial part (i.e., Input part), as well as for the GTCI as a whole.

\section{Analysis and discussion of the results of empirical research}

The author begins the analysis of the results of empirical research by measuring the position of Latvia among the world's countries according to lifelong learning's components over three years - from 2018 to 2020. 


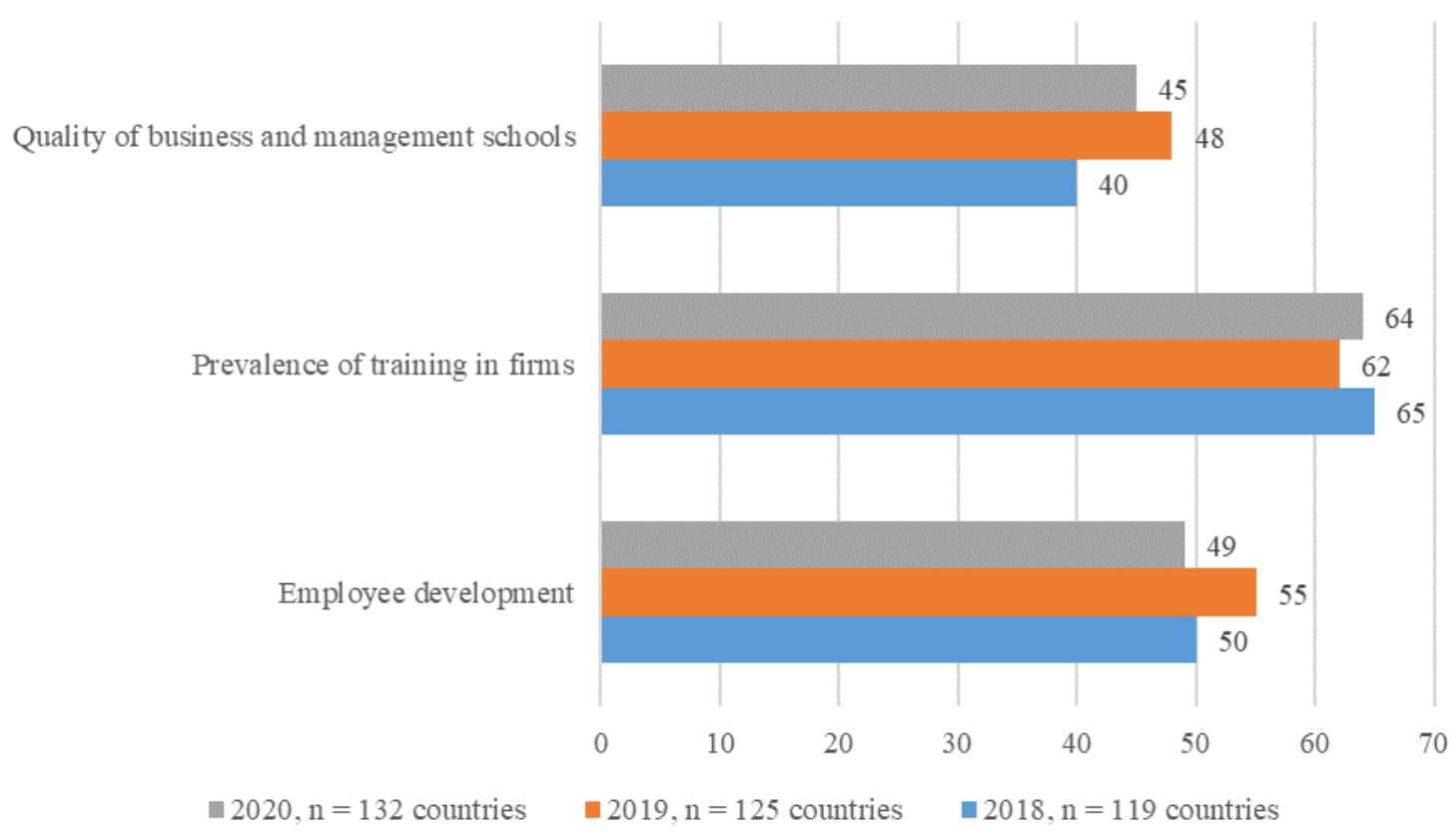

Fig. 4. The rank of Latvia among the world's countries according to lifelong learning's components, 2018-2020

Source: elaborated by the author based on the data of INSEAD et al., 2018, 2019, 2020.

As the data in Figure 4 show, for all three lifelong learning's components measured within the GTCI, Latvia consistently occupies an approximately middle position in the ranking of the world's countries. Compared to other countries of the world, Latvia is doing the worst with such lifelong learning's component as "Prevalence of training in firms": 65th in the world in 2018, 62nd in 2019 and 64th in 2020. The best position in Latvia is for such a lifelong learning's component as "Quality of business and management schools". In terms of the "Employee development" component, Latvia's position against the background of the world's countries is average, but at the same time it is constantly improving: for example, if in 2018 Latvia was ranked 50th in this component among 119 countries of the world, then in 2020 it is already 49th place among 132 countries of the world.

The following table shows the position of Latvia among the EU countries only for one lifelong learning's component - "Employee development", which is the subject of this study. 
INSIGHTS INTO REGIONAL DEVELOPMENT

ISSN 2669-0195 (online) http://jssidoi.org/jesi/

2021 Volume 3 Number 4 (December)

http://doi.org/10.9770/IRD.2020.3.4(6)

Table 3. The position of Latvia among the EU countries according to lifelong learning's component “Employee development”, 2018-2020

\begin{tabular}{|c|c|c|c|c|c|c|}
\hline \multirow[b]{2}{*}{ EU countries* } & \multicolumn{2}{|c|}{$2018, N=28$ countries } & \multicolumn{2}{|c|}{$2019, N=28$ countries } & \multicolumn{2}{|c|}{$2020, \mathrm{~N}=27$ countries } \\
\hline & $\begin{array}{c}\text { Scores, } \\
\text { from } 0 \text { to } 100\end{array}$ & Rank & $\begin{array}{c}\text { Scores, } \\
\text { from } 0 \text { to } 100\end{array}$ & Rank & $\begin{array}{c}\text { Scores, } \\
\text { from } 0 \text { to } 100\end{array}$ & Rank \\
\hline Sweden & 91.58 & 1 & 86.94 & 4 & 83.35 & 3 \\
\hline Luxembourg & 91.25 & 2 & 88.68 & 1 & 90.11 & 1 \\
\hline Netherlands & 89.23 & $3-4$ & 87.00 & 3 & 84.45 & 2 \\
\hline Finland & 89.23 & $3-4$ & 84.82 & 5 & 80.65 & 5 \\
\hline Austria & 84.18 & 5 & 78.34 & 8 & 74.00 & 8 \\
\hline Germany & 82.83 & 6 & 87.54 & 2 & 79.37 & 6 \\
\hline Denmark & 82.15 & 7 & 82.20 & 6 & 82.06 & 4 \\
\hline Belgium & 81.48 & 8 & 79.05 & 7 & 73.24 & 9 \\
\hline United Kongdom & 72.73 & 9 & 67.26 & 11 & - & - \\
\hline Ireland & 69.36 & 10 & 73.14 & 9 & 74.04 & 7 \\
\hline France & 69.36 & 11 & 67.63 & 10 & 67.34 & 10 \\
\hline Estonia & 64.31 & 12 & 62.76 & 13 & 60.46 & 12 \\
\hline Lithuania & 60.61 & 13 & 60.01 & 14 & 61.41 & 11 \\
\hline Czech Republic & 58.92 & 14 & 63.30 & 12 & 58.74 & 13 \\
\hline Malta & 56.57 & 15 & 58.23 & 15 & 51.36 & 15 \\
\hline Slovenia & 49.16 & 16 & 46.37 & 17 & 51.79 & 14 \\
\hline Latvia & 46.46 & 17 & 43.62 & 19 & 48.79 & 17 \\
\hline Portugal & 43.77 & 18 & 45.10 & 18 & 45.37 & 19 \\
\hline Poland & 41.75 & 19 & 40.06 & 21 & 40.54 & 20 \\
\hline Slovak Republic & 40.40 & 20 & 41.91 & 20 & 48.40 & 18 \\
\hline Greece & 37.37 & 21 & 31.90 & 22 & 30.27 & 22 \\
\hline Cyprus & 33.67 & 22 & 46.74 & 16 & 49.32 & 16 \\
\hline Spain & 30.98 & 23 & 31.60 & 23 & 37.04 & 21 \\
\hline Bulgaria & 26.26 & 24 & 19.14 & 26 & 24.01 & 25 \\
\hline Romania & 26.26 & 25 & 17.80 & 27 & 23.73 & 26 \\
\hline Hungary & 23.23 & 26 & 24.85 & 25 & 29.28 & 23 \\
\hline Italy & 22.22 & 27 & 27.57 & 24 & 28.53 & 24 \\
\hline Croatia & 21.21 & 28 & 12.42 & 28 & 13.81 & 27 \\
\hline
\end{tabular}

* Countries ranked according to the rank in 2018 .

Source: calculated and elaborated by the author based on the data of INSEAD et al., 2018, 2019, 2020.

As the data in Table 3 show, in terms of the "Employee development" component, Latvia's position among the EU countries is consistently below the average: 17th place in 2018, 19th - in 2019 and 17th again, but already among the remaining 27 EU countries - in 2020. In turn, the best situation with employee development is observed in the countries of Western and Northern Europe: Sweden, Luxembourg, Netherlands, Finland.

Thus, empirical data show that Latvia cannot be considered a learning society, especially in comparison with other EU countries. The question arises: why is this happening despite the fact that in Latvia, both in political and scientific space, the importance of the continuous development of people's knowledge and skills is declared? For example, "Sustainable Development Strategy of Latvia until 2030" emphasized: "Our main capital is people, their abilities, knowledge and talent" (MEPRD of the Republic of Latvia, 2021). Furthermore, the Latvian "Human Development Report 2006/2007. Human Capital" noted that in industrial societies competitiveness and prosperity 


\section{INSIGHTS INTO REGIONAL DEVELOPMENT}

ISSN 2669-0195 (online) http://jssidoi.org/jesi/

2021 Volume 3 Number 4 (December)

http://doi.org/10.9770/IRD.2020.3.4(6)

are determined by means of production and other material values. In turn, in a knowledge society, the main source of well-being and development is a set of human abilities and skills (Zobena, 2007).

A possible answer, requiring empirical verification, to the question of why Latvia (like many other countries of the world and the EU) is still not a learning society, may be the assumption that the economic importance of employee professional development in the modern world in reality is not very high and therefore it is not very attractive to both the employees themselves and their employers.

To empirically measure the economic importance of employee professional development in the modern world, the author considers GDP per capita (PPP) as an indicator of the economic performance of the modern world's countries (Porter, 2003; Boronenko et al., 2014; Kondratiuk-Nierodzinska, 2016; Selivanova -Fyodorova et al., 2021), as well as the belonging of countries to income groups (INSEAD et al., 2018, 2019, 2020). Further, the author, using various methods, measures the relationship of both of these indicators with indicators of lifelong learning in general and the development of workers in particular.

Table 4. Correlation between GDP per capita of the world's countries and sub-pillars of the "Grow talents" as well as lifelong learning's components, 2018-2020

\begin{tabular}{|c|c|c|c|c|c|c|}
\hline \multirow[b]{2}{*}{ Variables } & \multicolumn{2}{|c|}{$2018, \mathrm{n}=119$ countries } & \multicolumn{2}{|c|}{$2019, n=125$ countries } & \multicolumn{2}{|c|}{$2020, n=132$ countries } \\
\hline & $\begin{array}{c}\text { Correlation with } \\
\text { GDP per capita } \\
(\mathrm{PPP})\end{array}$ & $\begin{array}{c}\text { Statistical } \\
\text { signifi-cance, } \\
\text { p-value }\end{array}$ & $\begin{array}{c}\text { Correlation with } \\
\text { GDP per capita } \\
\text { (PPP) }\end{array}$ & $\begin{array}{c}\text { Statistical } \\
\text { signifi-cance, } \\
\text { p-value }\end{array}$ & $\begin{array}{c}\text { Correlation with } \\
\text { GDP per capita } \\
\text { (PPP) }\end{array}$ & $\begin{array}{c}\text { Statistical } \\
\text { signifi-cance, } \\
\text { p-value }\end{array}$ \\
\hline $\begin{array}{l}\text { Formal } \\
\text { education }\end{array}$ & $0.549 * *$ & 0.000 & $0.576^{* *}$ & 0.000 & $0.618 * *$ & 0.000 \\
\hline $\begin{array}{l}\text { Access to growth } \\
\text { opportunities }\end{array}$ & $0.673 * *$ & 0.000 & $0.715^{* *}$ & 0.000 & $0.690 * *$ & 0.000 \\
\hline $\begin{array}{l}\text { Lifelong } \\
\text { learning, incl.: }\end{array}$ & $0.706 * *$ & 0.000 & $\mathbf{0 . 7 0 5} * *$ & 0.000 & $\mathbf{0 . 7 1 4} * *$ & 0.000 \\
\hline $\begin{array}{l}\text { - Quality of } \\
\text { business and } \\
\text { management } \\
\text { schools }\end{array}$ & $0.634 * *$ & 0.000 & $0.612 * *$ & 0.000 & $0.630 * *$ & 0.000 \\
\hline $\begin{array}{l}\text { - Prevalence of } \\
\text { training in firms }\end{array}$ & $0.246^{*}$ & 0.018 & $0.211 *$ & 0.046 & $0.201 *$ & 0.049 \\
\hline $\begin{array}{l}\text { - Employee } \\
\text { development }\end{array}$ & $0.692 * *$ & 0.000 & $0.706 * *$ & 0.000 & $0.700 * *$ & 0.000 \\
\hline
\end{tabular}

As the data in Table 4 show, the state of lifelong learning in general and especially that of its component "Employee development" is quite strong and statistically significant (and at the same time quite stable) correlates with the indicator of countries' economic performance - GDP per capita (PPP). It is noteworthy that the relationship between lifelong learning and GDP per capita in the modern world's countries is consistently stronger than the relationship between formal education and GDP per capita.

In order to clarify the direction of the relationship between lifelong learning / employee development and the economic performance of the modern world's countries, the author conducted a regression analysis. Regression analysis will empirically test the assumption that lifelong learning and employee development are factors, and the economic performance of a country is the result. 
INSIGHTS INTO REGIONAL DEVELOPMENT

ISSN 2669-0195 (online) http://jssidoi.org/jesi/

2021 Volume 3 Number 4 (December)

http://doi.org/10.9770/IRD.2020.3.4(6)

Table 5. Beta-coefficients and factors' statistical significance in the regression equation,

GDP per capita of the world's countries (resulting variable),

sub-pillars of the "Grow talents" and lifelong learning's components (factor variables), 2018-2020

\begin{tabular}{|l|c|c|c|c|c|c|}
\hline \multirow{2}{*}{ Variables } & \multicolumn{2}{|c|}{$2018, \mathrm{n}=119$ countries } & \multicolumn{2}{c|}{$2019, \mathrm{n}=125$ countries } & \multicolumn{2}{c|}{$2020, \mathrm{n}=132$ countries } \\
\cline { 2 - 6 } & $\begin{array}{c}\text { Beta-coefficient } \\
\text { in the regression } \\
\text { equation }\end{array}$ & $\begin{array}{c}\text { Statistical } \\
\text { signifi-cance, } \\
\mathrm{p} \text {-value }\end{array}$ & $\begin{array}{c}\text { Beta-coefficient } \\
\text { in the regression } \\
\text { equation }\end{array}$ & $\begin{array}{c}\text { Statistical } \\
\text { signifi-cance, } \\
\text { p-value }\end{array}$ & $\begin{array}{c}\text { Beta-coefficient } \\
\text { in the regression } \\
\text { equation }\end{array}$ & $\begin{array}{c}\text { Statistical } \\
\text { signifi-cance, } \\
\text { p-value }\end{array}$ \\
\hline $\begin{array}{l}\text { Formal } \\
\text { education }\end{array}$ & 108.230 & & 145.178 & 254.686 & 348.420 \\
\hline $\begin{array}{l}\text { Access to growth } \\
\text { opportunities }\end{array}$ & 264.167 & 460.069 & & 20.301 \\
\hline $\begin{array}{l}\text { Lifelong } \\
\text { learning, incl.: }\end{array}$ & $\mathbf{5 2 0 . 8 8 3}$ & & 68.677 & & \\
\hline $\begin{array}{l}\text { - Quality of } \\
\text { business and } \\
\text { management } \\
\text { schools }\end{array}$ & 202.118 & & & & 79.059 \\
\hline $\begin{array}{l}\text { - Prevalence of } \\
\text { training in firms }\end{array}$ & 69.471 & & 74.636 & & 350.709 \\
\hline $\begin{array}{l}\text { - Employee } \\
\text { development }\end{array}$ & & & & & \\
\hline
\end{tabular}

* Correlation is significant at the 0.05 level (2-tailed).

** Correlation is significant at the 0.01 level (2-tailed).

Source: calculated and elaborated by the author based on the data of INSEAD et al., 2018, 2019, 2020 and using SPSS software.

The summarized results of the regression analysis presented in Table 5 confirm the author's assumption that lifelong learning and employee development are factors, and the economic performance of a country is the result. Moreover, lifelong learning is consistently almost the only one of the three sub-pillars of the GTCI's pillar "Grow talents", which for three years has statistically significantly increased the economic performance of the modern world's countries. In turn, lifelong learning's component "Employee development" is consistently practically the only one of the three lifelong learning's components, which for three years has statistically significantly increased the economic performance of the modern world's countries. Thus, we can say that lifelong learning is a statistically significant factor of the economic performance of the modern world's countries precisely due to its component "Employee development".

The following two tables show the results of the comparison of means of lifelong learning (Table 6) and employee development (Table 7) for four income groups of the modern world's countries. The application of this method will help to find out whether there are statistically significant differences between the income groups of the modern world's countries in terms of means of lifelong learning and employee development. 
INSIGHTS INTO REGIONAL DEVELOPMENT

ISSN 2669-0195 (online) http://jssidoi.org/jesi/

2021 Volume 3 Number 4 (December)

http://doi.org/10.9770/IRD.2020.3.4(6)

Table 6. Multiple comparisons of the state of lifelong learning among income groups of countries, statistical significance of mean difference (p-value), ${ }^{2} \mathbf{2 0 1 8 - 2 0 2 0}$

\begin{tabular}{|c|c|c|c|c|c|c|c|c|c|c|c|c|}
\hline \multirow{3}{*}{$\begin{array}{l}\text { Income } \\
\text { groups }\end{array}$} & \multicolumn{4}{|c|}{$2018, n=119$ countries } & \multicolumn{4}{|c|}{$2019, \mathrm{n}=125$ countries } & \multicolumn{4}{|c|}{$2020, \mathrm{n}=132$ countries } \\
\hline & \multicolumn{12}{|c|}{ Income groups of the world's countries by the population income* } \\
\hline & 1 & 2 & 3 & 4 & 1 & 2 & 3 & 4 & 1 & 2 & 3 & 4 \\
\hline $\begin{array}{l}\text { High } \\
\text { income } \\
\text { (1) }\end{array}$ & - & 0.000 & 0.000 & 0.000 & - & 0.000 & 0.000 & 0.000 & - & 0.000 & 0.000 & 0.000 \\
\hline $\begin{array}{l}\text { Upper- } \\
\text { middle } \\
\text { income } \\
\text { (2) }\end{array}$ & 0.000 & - & 0.095 & 0.043 & 0.000 & - & 0.220 & 0.011 & 0.000 & - & 0.355 & 0.006 \\
\hline $\begin{array}{l}\text { Lower- } \\
\text { middle } \\
\text { income } \\
\text { (3) }\end{array}$ & 0.000 & 0.095 & - & 0.469 & 0.000 & 0.220 & - & 0.142 & 0.000 & 0.355 & - & 0.046 \\
\hline $\begin{array}{l}\text { Low } \\
\text { income } \\
\text { (4) }\end{array}$ & 0.000 & 0.043 & 0.469 & - & 0.000 & 0.011 & 0.142 & - & 0.000 & 0.006 & 0.046 & - \\
\hline
\end{tabular}

* Mean difference among income groups of countries is statistically significant, if p-value is $<0.05$.

Source: calculated and elaborated by the author based on the data of INSEAD et al., 2018, 2019, 2020 and using SPSS software.

Table 7. Multiple comparisons of the state of employee development among income groups of countries, statistical significance of mean difference (p-value), ${ }^{*} 2018-2020$

\begin{tabular}{|c|c|c|c|c|c|c|c|c|c|c|c|c|}
\hline \multirow{3}{*}{$\begin{array}{l}\text { Income } \\
\text { groups }\end{array}$} & \multicolumn{4}{|c|}{$2018, n=119$ countries } & \multicolumn{4}{|c|}{$2019, n=125$ countries } & \multicolumn{4}{|c|}{$2020, n=132$ countries } \\
\hline & \multicolumn{12}{|c|}{ Income groups of the world's countries by the population income* } \\
\hline & 1 & 2 & 3 & 4 & 1 & 2 & 3 & 4 & 1 & 2 & 3 & 4 \\
\hline $\begin{array}{l}\text { High } \\
\text { income } \\
\text { (1) }\end{array}$ & - & 0.000 & 0.000 & 0.000 & - & 0.000 & 0.000 & 0.000 & - & 0.000 & 0.000 & 0.000 \\
\hline $\begin{array}{l}\text { Upper- } \\
\text { middle } \\
\text { income } \\
(2) \\
\end{array}$ & 0.000 & - & 0.310 & 0.185 & 0.000 & - & 0.463 & 0.069 & 0.000 & - & 0.561 & 0.011 \\
\hline $\begin{array}{l}\text { Lower- } \\
\text { middle } \\
\text { income } \\
\text { (3) }\end{array}$ & 0.000 & 0.310 & - & 0.596 & 0.000 & 0.463 & - & 0.248 & 0.000 & 0.561 & - & 0.041 \\
\hline $\begin{array}{l}\text { Low } \\
\text { income } \\
\text { (4) }\end{array}$ & 0.000 & 0.185 & 0.596 & - & 0.000 & 0.069 & 0.248 & - & 0.000 & 0.011 & 0.041 & - \\
\hline
\end{tabular}

* Mean difference among income groups of countries is statistically significant, if p-value is $<0.05$.

Source: calculated and elaborated by the author based on the data of INSEAD et al., 2018, 2019, 2020 and using SPSS software.

The results of the comparison of means of lifelong learning and employee development for four income groups of countries, presented in Tables 6 and 7, indicate that a statistically significant difference in both lifelong learning and employee development is consistently observed between the group of countries with high income (group 1) and all other groups - i.e. countries with middle and low income (groups 2, 3 and 4 together). Sometimes there is a statistically significant difference (more often - almost "on the threshold" of insignificance, when the p-value is very close to 0.05 ) between groups 2 and 4 or groups 3 and 4, but this does not change the overall stable and fairly clear picture - a group of countries with high income is very different from the modern world's countries with middle and low income precisely in that it includes mainly learning societies with a relatively high level of lifelong learning and employee development. 
The next two figures clearly compare means of lifelong learning and employee development across the highincome and middle / low-income groups of countries.

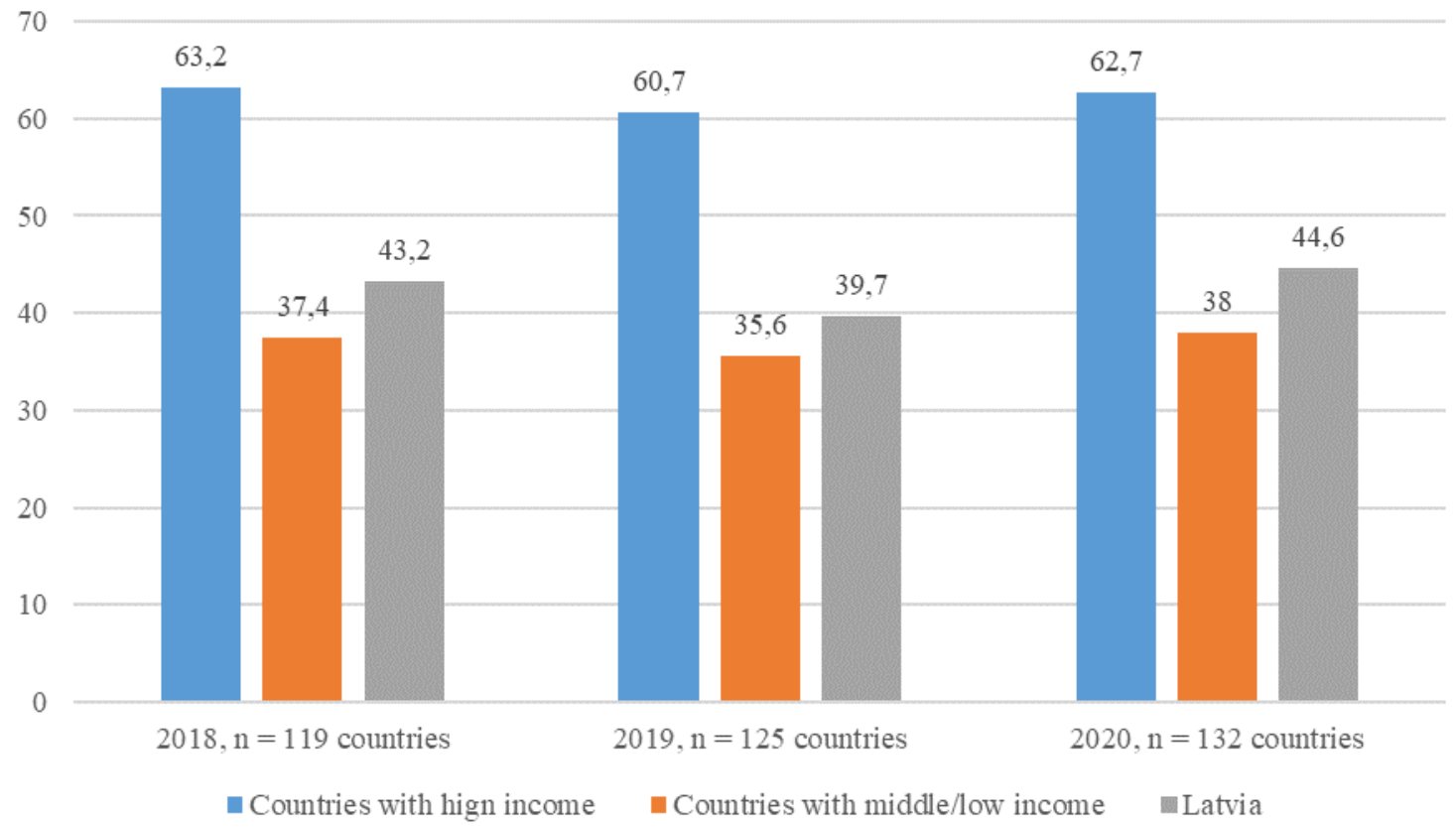

Fig. 5. Mean Difference between lifelong learning across income groups of countries, scores from 0 to $100,2018-2020$

Source: calculated and elaborated by the author based on the data of INSEAD et al., 2018, 2019, 2020 and using SPSS software. 


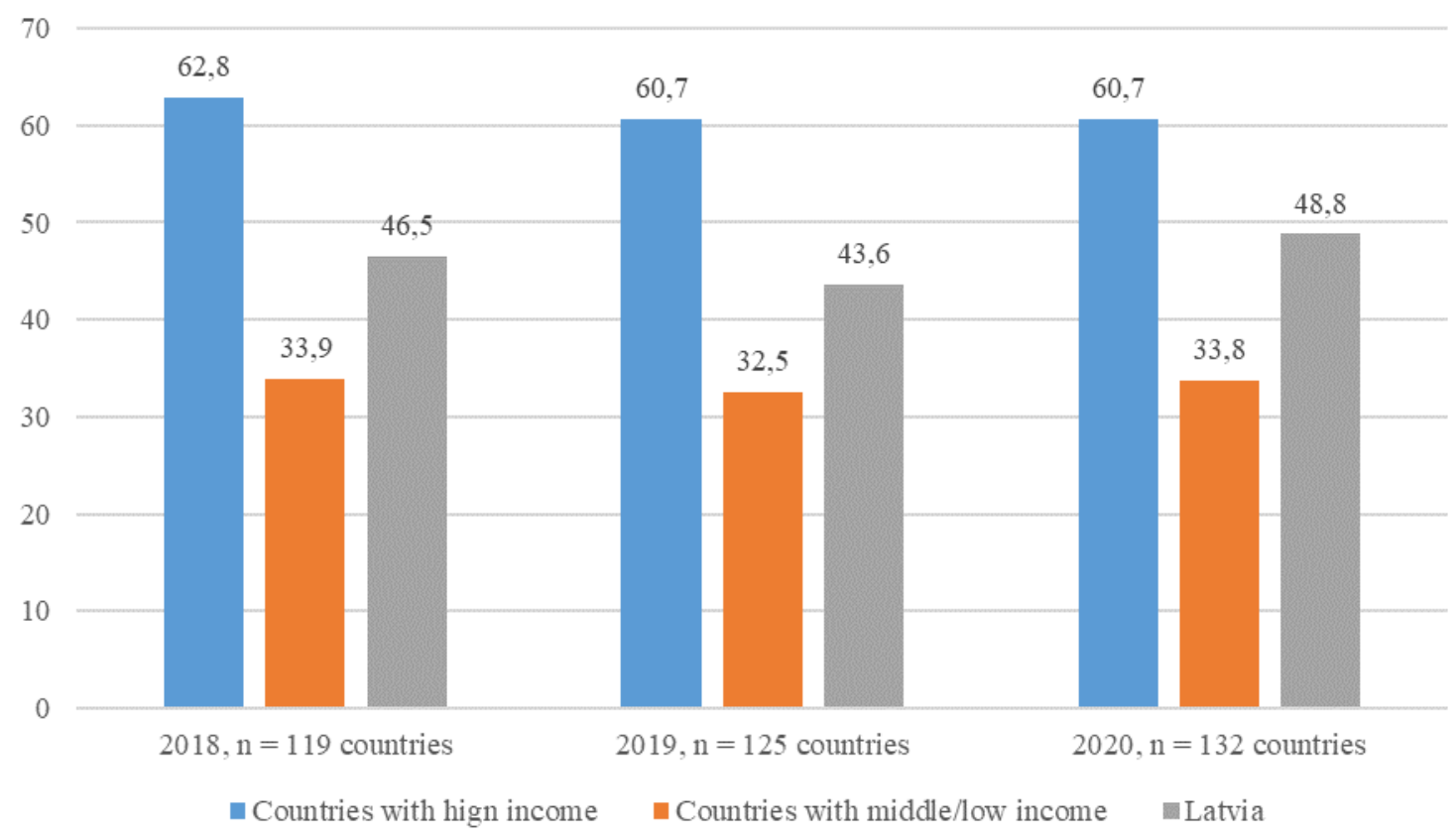

Fig. 6. Mean Difference between employee development across income groups of countries, scores from 0 to $100,2018-2020$

Source: calculated and elaborated by the author based on the data of INSEAD et al., 2018, 2019, 2020 and using SPSS software.

As shown by the data graphically presented in Figures 5 and 6, in the group of the modern world's countries with high income, means of lifelong learning and employee development are almost 2 times higher compared to the group of countries with middle / low income. As for Latvia, its position is consistently intermediate between the group of high-income countries and the group of middle / low-income countries in terms of employee development (Figure 6). In turn, in terms of lifelong learning, Latvia's position is closer to the group of middle / low-income countries (Figure 5). At the same time, according to the INSEAD (The Business School for the World) methodology, Latvia belongs to the group of high-income countries (INSEAD et al., 2018, 2019, 2020), which can be considered a kind of "credit of trust" from international organizations, which Latvia, according to the author, does not always justify - for example, in the field of lifelong learning and employee development.

The last, the fourth, method of discriminant analysis will help the author to confirm the results obtained by comparison of means. Using this method, the author will find out whether lifelong learning and employee development are "discriminatory" variables. Then, based on values of these variables, it is possible to predict in advance with a certain accuracy which group of countries - with high income or with middle / low income - a particular country will belong to.

The first two results of discriminant analysis presented in Tables 8 and 9 are test results and indicate the possibility of carrying out discriminant analysis as such on these particular samples of countries. The correlation coefficients (canonical correlations) between the calculated values of the discriminant functions and actual group memberships showed in Tables 8 and 9 are satisfactory (Sweet \& Grace-Martin, 2012). The test conducted using the Wilks' Lambda criteria for whether the mean values of the discriminant function differ significantly among themselves in both groups of countries - with a high income and with a middle / low income, showed a very high statistical significance $(\mathrm{p}<0.001)$ (Tables 8 and 9). 
INSIGHTS INTO REGIONAL DEVELOPMENT

ISSN 2669-0195 (online) http://jssidoi.org/jesi/

2021 Volume 3 Number 4 (December)

http://doi.org/10.9770/IRD.2020.3.4(6)

Table 8. The results of discriminant analysis for lifelong learning:

its discriminatory potential to divide the world's countries into income groups, 2018-2020

\begin{tabular}{|l|c|c|c|}
\hline \multicolumn{1}{|c|}{ Variables } & $2018, \mathrm{n}=119$ countries & $2019, \mathrm{n}=125$ countries & $2020, \mathrm{n}=132$ countries \\
\hline Canonical correlation* & 0.628 & 0.630 & 0.654 \\
\hline Wilks' Lambda** & 0.000 & 0.000 & 0.000 \\
\hline \multicolumn{3}{|c|}{ The level of correctly classified originally grouped cases, \% } \\
\hline $\begin{array}{l}\text { Countries with } \\
\text { high income }\end{array}$ & 67.4 & 65.3 & 79.2 \\
\hline $\begin{array}{l}\text { Countries with middle/low } \\
\text { income }\end{array}$ & 82.2 & 84.2 & 89.3 \\
\hline Total & 76.5 & 76.8 & 85.6 \\
\hline
\end{tabular}

* Correlation coefficient between values of the discriminant function and actual group membership.

** Test to determine whether the mean values of the discriminant function in both groups differ statistically significantly.

Source: calculated and elaborated by the author based on the data of INSEAD et al., 2018, 2019, 2020 and using SPSS software.

Table 9. The results of discriminant analysis for employee development: its discriminatory potential to divide the world's countries into income groups, 2018-2020

\begin{tabular}{|c|c|c|c|}
\hline Variables & $2018, n=119$ countries & $2019, \mathrm{n}=125$ countries & $2020, n=132$ countries \\
\hline Canonical correlation* & 0.603 & 0.612 & 0.621 \\
\hline Wilks'Lambda** & 0.000 & 0.000 & 0.000 \\
\hline \multicolumn{4}{|c|}{ The level of correctly classified originally grouped cases, $\%$} \\
\hline $\begin{array}{l}\text { Countries with } \\
\text { high income }\end{array}$ & 67.4 & 65.3 & 77.1 \\
\hline $\begin{array}{l}\text { Countries with middle/low } \\
\text { income }\end{array}$ & 80.8 & 82.9 & 83.3 \\
\hline Total & 75.6 & 76.0 & 81.1 \\
\hline
\end{tabular}

* Correlation coefficient between values of the discriminant function and actual group membership.

** Test to determine whether the mean values of the discriminant function in both groups differ statistically significantly.

Source: calculated and elaborated by the author based on the data of INSEAD et al., 2018, 2019, 2020 and using SPSS software.

The main result of discriminant analysis (for which it is carried out) is the mean of correctness of predictions for each case that falls into the corresponding group of countries. In the case of lifelong learning, from $65.3 \%$ in 2019 to $77.1 \%$ in 2020 of cases correctly predicted to fall into the group of countries with high income and from $82.2 \%$ in 2018 to $89.3 \%$ in 2020 - into the group of countries with middle / low income (Table 8). Thus, based on lifelong learning indicator, it is easier to predict whether a country is in the middle / low income group than in the high income group. In other words, if a country has a high value of lifelong learning's indicator, then it most likely will not fall into the group of countries with middle / low income, but at the same time it is less obvious that it will fall into the group of countries with high income. The total level of correctly classified originally grouped cases within the discriminant model of lifelong learning is relatively high (Sweet \& Grace-Martin, 2012) and constantly increasing: $76.5 \%$ in $2018,76.8 \%$ in $2019,85.6 \%$ in 2020 (Table 8). This means that in more than $85 \%$ of cases in 2020, based on the value of the lifelong learning's indicator in a country, it is possible to determine which income group this country will belong to.

As for the employee development indicator included in the GTCI's sub-pillar "Lifelong learning" and empirically interpreted as an answer of experts to the question: "In your country, to what extent do companies invest in training and employee development?", here, according to the results of discriminant analysis, the situation is almost the same as in the case of lifelong learning. That is, in more than $80 \%$ of cases in 2020, it is possible to find out whether a country has a high or medium / low income, knowing only to what extent do companies invest in training and employee development in that country. In the case of a relatively high level of employee development, the country is most likely not to fall into the group with middle / low income, but at the same time, as in the case of lifelong learning, it is less obvious that it will fall into the group with high incomes. Most likely, 


\section{INSIGHTS INTO REGIONAL DEVELOPMENT}

ISSN 2669-0195 (online) http://jssidoi.org/jesi/

2021 Volume 3 Number 4 (December)

http://doi.org/10.9770/IRD.2020.3.4(6)

the probabilities of indicators of both lifelong learning in general and employee development in particular, as well as the probabilities of indicators of GDP per capita (PPP) in both income groups of countries are normally distributed (which is typical for the distribution of probabilities of almost all physical and socio-economic indicators (Selivanova-Fyodorova et al., 2018; Komarova et al., 2019), and Latvia is "at the tail" of this distribution in a group of high-income countries.

Thus, using four methods of quantitative data analysis, the author proves the economic importance of employee professional development in the modern world. This provides a scientific basis for the practical implementation of management tasks using the tools presented in the scheme of conceptual understanding of sustainable management of employee professional development as a component of lifelong learning within the economic paradigm (Figure 2).

\section{Conclusions}

The main limitations for this study are the time period (from 2018 to 2020), as well as the empirical interpretation of the subject of this study - employee professional development - in the framework of GTCI, limited to measuring to what extent do companies invest in training and employee development.

Using the set of the quantitative data analysis methods, the author proves the following:

(1) the state of lifelong learning in general, and especially that of its component "Employee development" is quite strong (stronger than the state of formal education), statistically significant and relatively stable correlated with an indicator of the economic performance of the modern world's countries - GDP per capita (PPP);

(2) the regression analysis confirmed the author's assumption that lifelong learning and employee development are factors, but the economic performance of a country is the result; at the same time, lifelong learning is a statistically significant factor of the economic performance of the modern world's countries precisely due to its component such as "Employee development";

(3) the comparison of means of lifelong learning and employee development for four income groups of countries showed that the group of countries with high income differs from the group of countries with middle / low income precisely in that it includes mainly learning societies with relatively high level of lifelong learning and employee development;

(4) the discriminant analysis showed that depending on the state of lifelong learning and employee development in the modern world's countries, it is possible to determine the income level (high or middle / low) in these countries by about $80-85 \%$.

The author concludes that in the modern world, employee development is mainly a factor, but also an indicator of competitiveness and economic performance of countries, since significant investments are required to implement employee professional development. Nevertheless, the sustainable management of lifelong learning and the selfmotivation of employees helps to create a learning society not only based on material investment, but also through the development of a learning culture.

\section{References}

Aspin, D.; Chapman, J. 2007. Lifelong Learning Concepts and Conceptions. Aspin D. (ed.). Philosophical Perspectives on Lifelong Learning. Springer, 17-34.

Beqiri, Th.; Mazreku, I. 2020. Lifelong learning, training and development employee's perspective. Journal of Educational and Social Research, 10(2): 94-102. https://doi.org/10.36941/jesr-2020-0029 


\section{INSIGHTS INTO REGIONAL DEVELOPMENT}

ISSN 2669-0195 (online) http://jssidoi.org/jesi/

2021 Volume 3 Number 4 (December)

http://doi.org/10.9770/IRD.2020.3.4(6)

Bersin, J.; Zao-Sanders, M. 2019. Making learning a part of everyday work, Harvard Business Review. Retrieved from https://hbr.org/2019/02/making-learning-a-part-of-everyday-work

Boeren, E. 2016. Lifelong Learning Participation in a Changing Policy Context. An Interdisciplinary Theory. London: Palgrave Macmillan.

Boronenko, V. 2007. Klasteru pieeja regionu attistibai zinasanu ekonomikas apstaklos [Cluster approach for regional development in the conditions of knowledge economy]. Daugavpils: DU publishing house "Saule". [in Latvian]

Boronenko, V.; Mensikovs, V.; Lavrinenko, O. 2014. The impact of EU accession on the economic performance of the countries' internal (NUTS 3) regions. Proceedings of Rijeka School of Economics, 32(2): 313-341.

Chen, G.; Klimoski, R. 2007. Training and development of human resources at work: Is the state of our science strong? Human Resource Management Review, 17(2): 180-190. https://doi.org/10.1016/j.hrmr.2007.03.004

Dahlman, C.; Douglas, Zh.; Shuilin, W. 2007. Enhancing China's Competitiveness through Lifelong Learning. Washington, DC: World Bank. Retrieved from https://openknowledge.worldbank.org/handle/10986/6702

Edwards, R.; Raggatt, P.; Small, N. (eds.). 1995. The Learning Society: Challenges and Trends. Second Edition. Routledge.

EC (European Commission). 1995. Teaching and Learning: Towards the Learning Society. White Paper on Education and Training. Retrieved from https://europa.eu/documents/comm/white_papers/pdf/com95_590_en.pdf

EC (European Commission). 2000. A Memorandum on Lifelong Learning. Brussels: European Commission.

Galindo-Rueda, F.; Vignoles, A.; Jenkins, A.; Wolf, A. 2003. The determinants and labour market effects of lifelong learning. Applied Economics, 35(16): 1711-1721. https://doi.org/10.1080/0003684032000155445

Husen, T. 1974. The Learning Society. London: Methuen \& Co.

Hutchins, R. 1968. The Learning Society. Chicago: The University of Chicago Press.

ILO (International Labour Organization). 2019. Lifelong learning: concepts, issues and actions. Concept Paper. Retrieved from https://www.ilo.org/skills/pubs/WCMS_711842/lang--en/index.htm.

INSEAD (The Business School for the World), the Adecco Group, Tata Communications. 2017. The Global Talent Competitiveness Index 2017: Talent and Technology. France: Fontainebleau.

INSEAD (The Business School for the World), the Adecco Group, Tata Communications. 2018. The Global Talent Competitiveness Index 2018: Diversity for Competitiveness. France: Fontainebleau.

INSEAD (The Business School for the World), the Adecco Group, Tata Communications. 2019. The Global Talent Competitiveness Index 2019: Entrepreneurial Talent and Global Competitiveness. France: Fontainebleau.

INSEAD (The Business School for the World), the Adecco Group, Tata Communications. 2020. The Global Talent Competitiveness Index 2020: Global Talent in the Age of Artificial Intelligence. France: Fontainebleau.

Jarvis, P. 2000. Globalisation, the learning society and comparative education, Comparative Education, 36(3): 343-355. Retrieved from https://www.jstor.org/stable/3099622

Jarvis, P. 2006. Beyond the learning society: globalisation and the moral imperative for reflective social change, International Journal of Lifelong Education, 25(3): 201-211. https://doi.org/10.1080/02601370600697011

Komarova, V.; Vasserman, Y.; Selivanova-Fyodorova, N. 2019. Uroven' razvitiia chelovecheskogo potentsiala: global'naia differentsiatsiia [Human development level: the global differentiation]. Bulletin of Perm National Reearch Polytechnic University: Social and Economic Sciences, 4: 145-160. [in Russian]

Kondratiuk-Nierodzinska, M. 2016. New knowledge generation capabilities and economic performance of Polish regions. Equilibrium, Quarterly Journal of Economics and Economic Policy, 11(3): 451-471. https://doi.org/10.12775/EQUIL.2016.021 


\section{INSIGHTS INTO REGIONAL DEVELOPMENT}

ISSN 2669-0195 (online) http://jssidoi.org/jesi/

2021 Volume 3 Number 4 (December)

http://doi.org/10.9770/IRD.2020.3.4(6)

Kyndt, E.; Baert, H. 2013. Antecedents of employees' involvement in work-related learning: a systematic review, Review of Educational Research, 83(2): 273-313. https://doi.org/10.3102/0034654313478021

Lapina, I.; Aramina, D. 2011. Cilvekkapitala attistiba, balstita uz kompetencem un izglitibas kvalitati [Human capital development, based on competence and education quality], Economics and Business. Economy, 21: 60-66. [in Latvian]

Lundvall, B.-A.; Johnson, B. 1994. The learning economy, Journal of Industry Studies, 2(1): 23-42. https://doi.org/10.1080/13662719400000002

Lundvall, B.-A. 2016. The Learning Economy and the Economics of Hope. London: Anthem Press.

MEPRD (Ministry of Environmental Protection and Regional Development) of the Republic of Latvia. 2021. Sustainable Development Strategy of Latvia until 2030. Retrieved from https://www.varam.gov.lv/sites/varam/files/content/files/lias_2030_en.pdf

OECD (Organization for Economic Cooperation and Development). 2019. OECD Skills Strategy 2019: Skills to Shape a Better Future. Retrieved from https://www.oecd.org/publications/oecd-skills-strategy-2019-9789264313835-en.htm

Panitsides, E.; Griva, E.; Chostelidou, D. 2012. European Union policies on lifelong learning: in-between competitiveness enhancement and social stability reinforcement, Procedia - Social and Behavioral Sciences, 46: 548-553. https:/doi/org/10.1016/j.sbspro.2012.05.158

Popescu, A. 2011. The learning society as a key for development, Proceedings of the 7th Administration and Public Management International Conference, Bucharest, June 21-22. Retrieved from https://www.researchgate.net/publication/227489960_THE_LEARNING_SOCIETY_AS_a_KEY_FOR_DEVELOPMENT

Porter, M. 2003. The economic performance of regions, Regional Studies, 37(6-7): 549-578.

https://doi.org/10.1080/0034340032000108688

PwC. 2021. A Leadership Agenda to Take on Tomorrow. 24th Annual Global CEO Survey. Retrieved from https://www.pwc.com/gx/en/ceo-survey/2021/reports/pwc-24th-global-ceo-survey.pdf

Raven, Dzh. 2021. Kompetentnost' v sovremennom obschestve. Viiavlenie, razvitie i realizatsiia [A competence in the modern society: identification, development and realization]. Moscow: Litres. [in Russian]

Rivza, B. (ed.). 2018. Zinasanu ekonomika Latvijas lauku un regionu dzivotspejai [Knowledge economy for Latvian rural and regional resiliency]. Jelgava: Jelgava printing house. [in Latvian]

Saisana, M.; Becker, W.; Dominguez-Torreiro, M. 2017. JRC statistical audit of the Global Talent Competitiveness Index 2017. INSEAD (The Business School for the World), the Adecco Group, Tata Communications. The Global Talent Competitiveness Index 2017: Talent and Technology. France: Fontainebleau, 85-96.

Sannikova, A. 2015. Economic Aspects of Lifelong Education in Latvia. Summary of the Doctoral Thesis. Jelgava: Latvia University of Agriculture. Retrieved from https://llufb.llu.lv/dissertation-

summary/education/Aija_Sannikova_prom_darba_kopsavilkums2016_LLU_ESAF.pdf

Sekhar, Ch. 2020. The inclusion of sustainability in management education institutions: Assessing critical barriers using the DEMATEL method. International Journal of Sustainability in Higher Education, 21(2). https://doi.org/10.1108/IJSHE-02-2019-0100

Selivanova-Fyodorova, N.; Komarova, V.; Vasserman, Y.; Tutaeva, D. 2018. Differentsiatsiia urovnia chelovecheskogo razvitiia v stranakh mira i ikh regionakh [Differentiation of the level of human development in the world's countries and their regions]. Social Sciences Bulletin, 27(2): 73-102. https://doi.org/10.9770/szv.2018.2(5) [in Russian]

Selivanova-Fyodorova, N.; Leikuma-Rimicane, L.; Ignatyevs, S.: Heimanis, B. 2021. Iavliaetsia li talent dvigatelem ekonomicheskogo razvitiia stran sovremennogo mira? [Is talent the engine of countries' economic development in the modern world?] Social Sciences Bulletin, 33(2): 103-127. https://doi.org/10.9770/szv.2021.2(6) [in Russian]

Seriakova, S.; Kravchenko, V. 2020. Dopolnitel'noe professional'noe obrazovanie v Rossii i stranakh Zapadnoi Evropi: sopostavitel'nii analiz [Additional vocational education in Russia and Western European countries: a comparative analysis]. Moscow: Litres. [in Russian]

$\mathrm{Su}$, Y.-H. 2007. The learning society as itself: lifelong learning, individualization of learning, and beyond education. Studies in Continuing Education, 29(2): 195-206. 


\section{INSIGHTS INTO REGIONAL DEVELOPMENT}

ISSN 2669-0195 (online) http://jssidoi.org/jesi/

2021 Volume 3 Number 4 (December)

http://doi.org/10.9770/IRD.2020.3.4(6)

Sungsup, R.; Shanti, J.; Rupert, M. (eds.). 2021. Powering a Learning Society during an Age of Disruption. Springer.

Sweet, S.; Grace-Martin, K. 2012. Data Analysis with SPSS: A First Course in Applied Statistics, Fourth Edition. Pearson.

Tindemans, B.; Dekocke, V. 2020. The Learning Society. Brussels. Retrieved from https://www.oecd.org/skills/centre-forskills/The_Learning_Society.pdf

UNESCO (United Nations Educational, Scientific and Cultural Organization). 2015a. Education 2030: Towards Inclusive and Equitable Quality Education and Lifelong Learning for All. Incheon Declaration. Retrieved from

http://unesdoc.unesco.org/images/0023/002338/233813M.pdf

UNESCO (United Nations Educational, Scientific and Cultural Organization). 2015b. Rethinking Education. Towards a Global Common Good? Retrieved from http://www.unesco.org/new/fileadmin/MULTIMEDIA/FIELD/Cairo/images/RethinkingEducation.pdf

UNESCO (United Nations Educational, Scientific and Cultural Organization). 2016. Partnering for Prosperity: Education for Green and Inclusive Growth. Global Education Monitoring Report 2016. Paris: UNESCO.

Webb, S.; Holford, J.; Hodge, S.; Milana, M.; Waller, R. 2019. Conceptualising lifelong learning for sustainable development and education 2030, International Journal of Lifelong Education, 38(3): 237-240. https://doi.org/10.1080/02601370.2019.1635353

Welton, M. 2005. Designing the Just Learning Society: A Critical Inquiry. Leicester: NIACE.

Zborovskij, G.; Ambarova, P. 2020. "Serebrianoe" obrazovanie kak resurs razvitiia regiona ["Silver" education as the resource of regional development], RUDN Journal of Sociology, 20(4): 939-952. https://doi.org/10.22363/2313-2272-2020-20-4-939-952 [in Russian]

Zobena, A. (ed.). 2007. Latvija. Parskats par tautas attistibu 2006/2007. Cilvekkapitals: mans zelts ir mana tauta? [Latvia. Human Development Report 2006/2007. Human capital: is my nation - my gold?] Riga: ASPRI. [in Latvian]

\section{Acknowledgement}

*This research was supported by the project, which has received funding from the European Union's Horizon 2020 research and innovation programme European Research Council (ERC) under the European Union's Horizon 2020 research and innovation programme Marie Sklodowska-Curie Research and Innovation Staff Exchanges ES H2020-MSCA-RISE-2014 CLUSDEVMED (2015-2019) Grant Agreement Number 645730730

Valdis JUKŠS is a Doctoral Candidate at the Faculty of Social Sciences in Daugavpils University (Latvia). His research interests: sustainable management, employee professional development, lifelong learning, learning society, learning economy.

ORCID ID: https://orcid.org/0000-0002-7028-1835

Make your research more visible, join the Twitter account of INSIGHTS INTO REGIONAL DEVELOPMENT: @IntoInsights

Copyright (C) 2021 by author(s) and VsI Entrepreneurship and Sustainability Center

This work is licensed under the Creative Commons Attribution International License (CC BY).

http://creativecommons.org/licenses/by/4.0/

(c) †) Open Access 